\title{
Genetic evidence for parapatric differentiation of two forms of the brackish-water nereidid polychaete Hediste atoka
}

\author{
HIROAKI TOSUJI ${ }^{1, *} \&$ MASANORI SATO ${ }^{2}$ \\ ${ }^{1}$ Department of Chemistry and Bioscience, Graduate School of Science and Engineering, Kagoshima University, Kagoshima, \\ Japan \\ ${ }^{2}$ Department of Earth and Environmental Sciences, Graduate School of Science and Engineering, Kagoshima University, \\ Kagoshima, Japan
}

Received 6 July 2010; Accepted 6 December 2010

\begin{abstract}
The phylogeography of local populations of the direct-developing estuarine polychaete Hediste atoka was examined by comparing the partial nucleotide sequences of the mitochondrial gene for cytochrome oxidase subunit I (COI) from 67 individuals collected from 27 sites that cover the majority of the distribution area of this species along the Japanese coasts, and from two sites of the Korean coasts. The phylogenetic trees drawn by four different methods (maximum likelihood, neighbor-joining, minimum evolution and maximum parsimony) showed consistently that populations of $H$. atoka could be divided into two parapatric forms: form A constituted all Korean and most Japanese populations except for those in southern Japan (southwestern Kyushu and the Ryukyu Islands), occupied by form B. No morphological differentiation has been detected between the two forms; the number of paragnath on the proboscis of each group was not significantly different from each other. The geographical distributions of these two forms did not overlap each other. These results suggest that cryptic speciation may occur in H. atoka.
\end{abstract}

Key words: COI, cryptic speciation, estuary, Nereididae, phylogeography, Polychaeta

\section{Introduction}

Hediste species (Nereididae, Polychaeta, Annelida) dominate in macrobenthic fauna in shallow brackish waters in the North Temperate Zone (Sato 1999, 2004). Three Hediste species, H. atoka Sato \& Nakashima, 2003, H. diadroma Sato \& Nakashima, 2003 and H. japonica (Izuka, 1908), are distributed in Asian estuaries (Sato \& Nakashima 2003). Hediste atoka is widely distributed around Japanese coasts extending north to Aomori Prefecture and south to Amami-oshima Island in Kagoshima Prefecture (Sato \& Nakashima 2003, Sato 2004). The spawning of the $H$. atoka occurs within estuaries without reproductive swarming; females spawn within the burrows (Sato \& Tsuchiya 1987), and fertilized eggs develop directly to benthic juveniles without a true planktonic phase (Sato \& Tsuchiya 1991). Therefore, it is expected that the level of gene flow is lower and genetic differentiation is higher among geographically separated populations in

* Corresponding author: Hiroaki Tosuji; E-mail, tosuji@sci.kagoshima-u. ac.jp
H. atoka than in the closely related species (e. g. H. diadroma) with a planktonic larval phase. In fact, this idea was confirmed by electrophoretic studies of allozymes (Sato \& Masuda 1997, Sato 1999).

Recent molecular investigations have contributed hugely to reveal cryptic species complexes without marked morphological differentiation (Bickford et al. 2006). Many examples of cryptic differentiation have been revealed by molecular techniques in polychaetes (Bastrop et al. 1998, Westheide \& Hass-Cordes 2001, Jolly et al. 2004, Audzijonyte et al. 2008, Virgilio et al. 2009).

In the present study, we examined the nucleotide sequences of a part of the mitochondrial cytochrome oxidase subunit I (COI) gene of 29 populations of H. atoka in Japan and in Korea to confirm the expected genetic differentiation among the populations. Our results show that marked parapatric differentiation has occurred in $H$. atoka.

\section{Materials and Methods}

\section{Materials}

67 individuals in total of Hediste atoka were collected 
Table 1. Sampling data.

\begin{tabular}{|c|c|c|c|c|}
\hline Site number ${ }^{1)}$ & Locality & Date & Form & $\mathrm{n}^{2)}$ \\
\hline 1 & Teshio-gawa River, Hokkaido Prefecture & 6 August 2008 & A & $2(1)$ \\
\hline 2 & Mu-kawa River, Hokkaido Prefecture & August 2002 & $\mathrm{~A}$ & $3(1)$ \\
\hline 3 & Shinjo-gawa River, Aomori Prefecture & 3 June 1992 & A & 3 \\
\hline 4 & Takase-gawa River, Aomori Prefecture & 1 June 1992 & A & 3 \\
\hline 5 & Obuchi-numa, Aomori Prefecture & 30 May 1992 & A & $2(2)$ \\
\hline 6 & Ashizaki, Ominato, Aomori Prefecture & 17 June 2007 & $\mathrm{~A}$ & $2(2)$ \\
\hline 7 & Idoura Lagoon, Sendai Bay, Miyagi Prefecture & 5 August 2008 & A & 3 \\
\hline 8 & Hinuma-gawa River, Ibaraki Prefecture & 5 March 2002 & A & $3(3)$ \\
\hline 9 & Kokufu-gawa River, Sado Island, Niigata Prefecture & 19 October 1990 & A & $1(1)$ \\
\hline 10 & Kumano-gawa River, Wakayama Prefecture & 3 January 1997 & A & $3(3)$ \\
\hline 11 & Ohhashi-gawa River, Shimane Prefecture & 3 April 2007 & A & $3(3)$ \\
\hline 12 & Yahata-gawa River, Hiroshima Prefecture & 25 February 1998 & A & $3(3)$ \\
\hline 13 & Tsuyasazaki, Fukuoka Prefecture & 31 March 1998 & A & 3 \\
\hline 14 & Wajiro-gawa River, Fukuoka Prefecture & 30 July 2000 & A & $3(3)$ \\
\hline 15 & Tara-gawa River, Saga Prefecture & 26 May 2007 & A & $1(1)$ \\
\hline 16 & Minamata-gawa River, Kumamoto Prefecture & 17 February 1991 & $\mathrm{~B}$ & $2(1)$ \\
\hline 17 & Kamino-kawa River, Kagoshima Prefecture & 14 November 2006 & $\mathrm{~B}$ & 2 \\
\hline 18 & Izaku-gawa River, Kagoshima Prefecture & 31 May 1991 & $\mathrm{~B}$ & $1(1)$ \\
\hline 19 & Anraku-gawa River, Kagoshima Prefecture & 13 June 2003 & A & $1(1)$ \\
\hline 20 & Hishida-gawa River, Kagoshima Prefecture & 13 June 2003 & A & $1(1)$ \\
\hline 21 & Kubota-gawa River, Kagoshima Prefecture & 30 March 1990 & A & $2(2)$ \\
\hline 22 & Omoi-gawa River, Kagoshima Prefecture & 26 Srptember 1991 & $\mathrm{~B}$ & $1(1)$ \\
\hline \multirow[t]{5}{*}{23} & Kotsuki-gawa River, Kagoshima Prefecture & 13 July 1990 & $\mathrm{~B}$ & $2(2)$ \\
\hline & & 23 February 2004 & $\mathrm{~B}$ & 1 \\
\hline & & 19 March 2004 & $\mathrm{~B}$ & 3 \\
\hline & & 3 April 2004 & $\mathrm{~B}$ & 1 \\
\hline & & 3 April 2006 & $\mathrm{~B}$ & 2 \\
\hline 24 & Nagata-gawa River, Kagoshima Prefecture & 25 February 1992 & $\mathrm{~B}$ & 2 \\
\hline 25 & Urauchi Bay, Kami-Koshikijima Island, Kagoshima Prefecture & 15 Mat 2003 & $\mathrm{~B}$ & $2(2)$ \\
\hline 26 & Ura-kawa River, Amami-Oshima Island, Kagoshima Prefecture & 19 May 1995 & $\mathrm{~B}$ & $1(1)$ \\
\hline 27 & Urahara-gawa River, Kikaijima Island, Kagoshima Prefecture & 23 August 2007 & A & $1(1)$ \\
\hline 28 & Jeju, Jeju Island & 18 August 2002 & A & $2(2)$ \\
\hline 29 & Yongyudo Island, Incheon & 20 October 2003 & $\mathrm{~A}$ & 2 \\
\hline
\end{tabular}

${ }^{1)}$ Corresponding to site numbers in Fig. 1.

${ }^{2)}$ DNA was analysed for all individuals. Some of them (numbers shown in parentheses) were used for morphological analyses.

from the intertidal flats at 27 sites in Japan and two sites in Korea (Table 1, Fig. 1). The species of these individuals were identified according to the key of Sato \& Nakashima (2003) based on morphological characteristics for mature worms. For immature worms, diagnostic electrophoretic patterns of lactate dehydrogenase were used for the species identification (Sato \& Masuda 1997). In addition, they all were identified by the diagnostic electrophoretic pattern of PCR-RFLP analyses of mitochondrial 16S rRNA gene (Tosuji \& Sato 2008).

The whole body or a part of the body of each fresh sample was frozen and stored at $-50^{\circ} \mathrm{C}$, or fixed in $75-99 \%$ ethanol and stored at $-20^{\circ} \mathrm{C}$ or room temperature prior to actual DNA isolation.

The following DNA analyses were carried out for all individuals, some of which were used for morphological analyses.

\section{Sequencing and Molecular Phylogenic Analysis}

Total DNA was extracted with the spin-column method (DNeasy Blood \& Tissue kit, QIAGEN) using the middle part of the worm ca. $0.5 \mathrm{~cm}$ in length, following the DNeasy protocol for animal tissues. In the samples preserved in ethanol, they were placed in a PBS (phosphatebuffered saline) for $30 \mathrm{~min}$ before DNA extraction. Polymerase chain reactions were performed using TaKaRa Ex Taq (Takara Bio Inc., Japan) on a thermal cycler, GeneAmp PCR System 9700 (PE Biosystems) or PC-320 Program Temp Control System (ASTEC, Japan). The universal DNA primers for mitochondrial COI, LCO1490 (5'-GGT CAA CAA ATC ATA AAG ATA TTG G-3') and HCO2198 (5' TAA ACT TCA GGG TGA CCA AAA AAT CA-3') (Folmer et al. 1994) were used and the cycling regimes were as follows: initial denaturation at $94^{\circ} \mathrm{C}$ for $1 \mathrm{~min}$; followed by 38 cycles of strand denaturation at $94^{\circ} \mathrm{C}$ for $30 \mathrm{sec}$, annealing at $50^{\circ} \mathrm{C}$ for $30 \mathrm{sec}$; and primer extension 


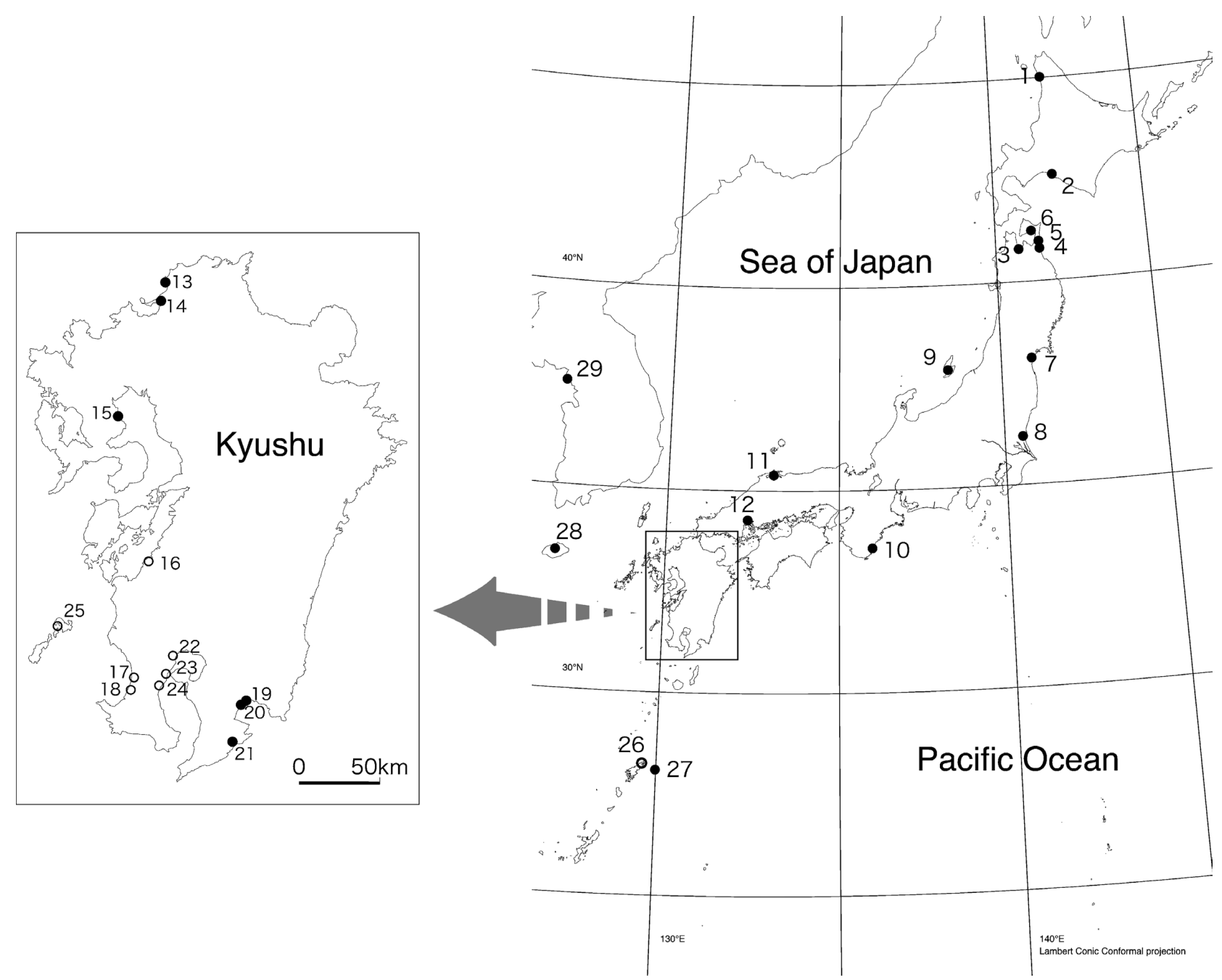

Fig. 1. Sampling sites of Hediste atoka. Site numbers are corresponding to those in Table 1. Closed circles, form A; open circles, form B.

at $72^{\circ} \mathrm{C}$ for $1 \mathrm{~min}$, and final 5 -minute extension at $72^{\circ} \mathrm{C}$ (Bastrop \& Blank 2006). Sometimes, HCO2198 does not work well so HCO709 (5'-AAT WAG AAT RTA KAC TTC WGG GTG-3') was used instead of HCO2198 (Blank et al. 2008). The PCR products were treated using ExoSAP-IT (GE Healthcare Life Sciences). The cycle sequencing reaction was carried out using BigDye 3.1 Terminator Cycle sequencing Ready Reaction Kit (Applied Biosystems) with either the forward or reverse primer (same as the DNA amplification) in 25 cycles of $96^{\circ} \mathrm{C}$ for $10 \mathrm{sec}, 50^{\circ} \mathrm{C}$ for $5 \mathrm{sec}$ and $60^{\circ} \mathrm{C}$ for $4 \mathrm{~min}$, then they were precipitated by ethanol/sodium acetate. Nucleotide sequences were determined using an automated DNA sequencer (ABI PRISM 3130xl Genetic Analyzer; Applied Biosystems).

Phylogenetic and molecular evolutionary analyses were inferred using MEGA (Molecular Evolutionary Genetics Analysis) software (Tamura et al. 2007).

We performed the maximum likelihood (ML) method based on the Tamura-Nei model (Tamura \& Nei 1993), neighbor-joining (NJ) method (Saitou \& Nei 1987), mini- mum evolution (ME) method (Rzhetsky \& Nei 1992) and maximum parsimony (MP) method (Eck \& Dayhoff 1966) analyses. For phylogenetic analysis, the gene sequences from $H$. japonica collected at Omuta-gawa River, Fukuoka Prefecture was used as an out-group.

\section{Morphological analyses}

A total of 38 individuals collected from 22 localities, which had been preserved in good condition, were used for morphological analyses (Table 1). In nereidid polychaetes, paragnath numbers on various areas of the proboscis are often available to distinguish morphologically similar but distinct species (Imajima 1972, Sato \& Nakashima 2003). The paragnaths in each of the groups on the proboscis in the ethanol-fixed specimens were counted under a stereomicroscope. The anterior maximum body width excluding the parapodia was also measured. 


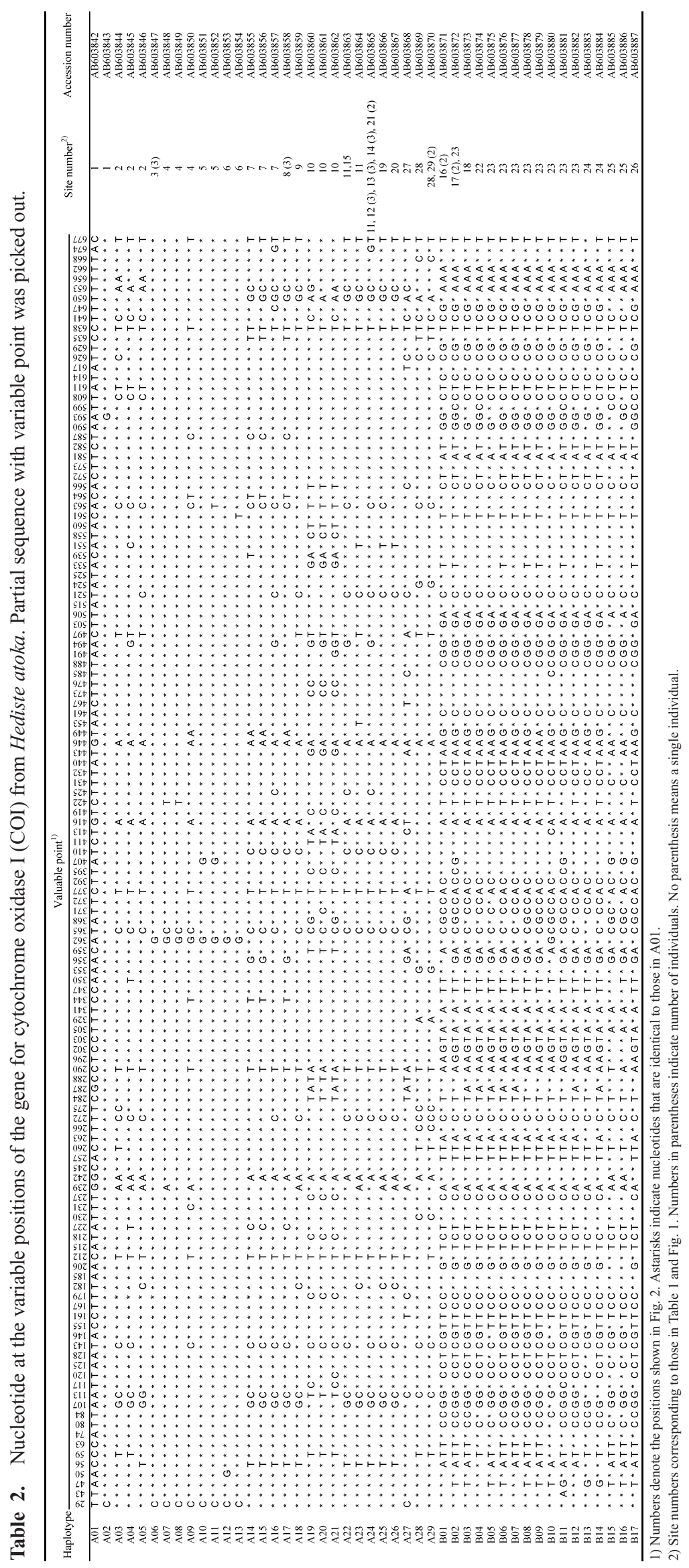


1

3 TCAACAAATCATAAAGATATTGGTACTTTATATTTTATCTTCGGAATATGATCCGGCCTT

$S \quad T \quad N \quad H \quad K \quad D$ I $G$ G

63 CTAGgaACATCAATAAGTCTTTTAATTCGAGCTGAATTAGGACAACCTGGATCCTTATTA

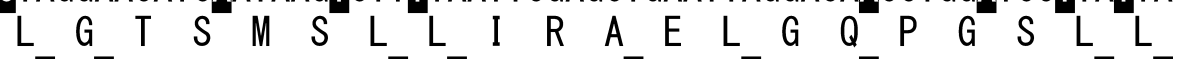

123 GGAAGAGATCAACTTTATAATACAATTGTTACCGCACACGCATTTTTAATAATTTTTTTT $G \quad S \quad D \quad Q \quad L \quad Y \quad N \quad T \quad I \quad V \quad T \quad A \quad H \quad A \quad F \quad L \quad M \quad I \quad F \quad F$

183 ctAGtAATACCAGTAATAATtgGAgGATtCGGAAATtGACTTGTACCTTTAATATTGGGG $L \vee M \quad P \quad V \quad M \quad I \quad G \quad G \quad F \quad G \quad N \quad W \quad L \quad V \quad P \quad L \quad M \quad L \quad G$

243 GCCCCTGATATAGCATTCCCTCGTCTTAATAATATAAGATTCTGGCTCCTTCCTCCATCG A P D M A F P R L N N M S F W L L P $P$ S

303 CTTACTCTTCTTtTATCAAGTGCAGCTGTTGAAAAGGTGTCGGCACAGGATGAACGGTA

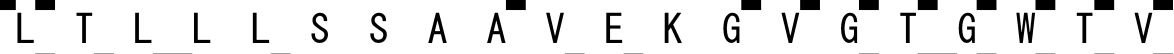

363 TATCCACCTTTAGCCAGAAATATTGCTCATGCTGGACCATCAGTAGATCTTGCGATTTTC $Y \quad P \quad P \quad L \quad A \quad S \quad N$ I $A$ H A

423 TCTCTTCATTTAGCAGGAGTTTCGTCTATTATAGGAGCATTAAACTTTATTACTACAGTT $S$ L $H$ L A G V S S I M G A L N F I T T V

483 ATTAATATACGATCCAAAGGTCTTCGTCTTGAACGAGTTCCATTATTTGTATGATCGGTA I N M R S K G L R L E R V P L F V W S V

543 ATAATTACAGCTATTTTACTACTACTTAGCTTACCAGTTCTAGCTGGAGCAATTACTATA $M$ I T A I L

603 CTTCTTACAGATCGAAATTTAAATACTGCATTCTTCGATCCTGCTGGTGGTGGTGACCCT

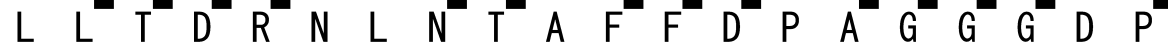

663 ATTCTTTATCAACACTTATTCTGATTTTTTGgTCACCCTGAAGTTTA I $L Y Y \quad Q H E$ F

Fig. 2. The nucleotide and deduced amino acid sequence of a part of mitochondrial gene for cytochrome oxidase I (COI) from the haplotype A01 of Hediste atoka. The variable positions are shown by black boxes.

Table 3. Comparison of paragnath numbers between form A and B.

\begin{tabular}{|c|c|c|c|c|c|c|c|c|}
\hline & \multirow{2}{*}{$\mathrm{n}$} & \multirow{2}{*}{$\begin{array}{c}\text { Body width } \\
\text { (mm) }\end{array}$} & \multicolumn{6}{|c|}{ Mean paragnath number \pm SD (range) } \\
\hline & & & I & $\mathrm{II}^{1)}$ & III & $\mathrm{IV}^{1)}$ & $\mathrm{VI}^{1)}$ & VII-VIII \\
\hline Form $\mathrm{A}^{2)}$ & 30 & $1.3-3.5$ & $\begin{array}{c}2.5+1.3 \\
(1-5)\end{array}$ & $\begin{array}{c}48.9+10.7 \\
(30-73)\end{array}$ & $\begin{array}{c}47.7+14.9 \\
(31-81)\end{array}$ & $\begin{array}{c}57.8+11.2 \\
(37-81)\end{array}$ & $\begin{array}{c}10.9+2.4 \\
(6-16)\end{array}$ & $\begin{array}{c}20.7+5.0 \\
(10-28)\end{array}$ \\
\hline Form $\mathrm{B}^{3)}$ & 8 & $2.3-3.7$ & $\begin{array}{c}3.1+1.2 \\
(2-6)\end{array}$ & $\begin{array}{c}53.4+12.7 \\
(41-80)\end{array}$ & $\begin{array}{c}56.0+9.8 \\
(38-70)\end{array}$ & $\begin{array}{c}63.3+9.9 \\
(56-86)\end{array}$ & $\begin{array}{c}12.1+4.6 \\
(8-21)\end{array}$ & $\begin{array}{c}24.6+6.3 \\
(16-36)\end{array}$ \\
\hline$p^{4)}$ & & & 0.15 & 0.30 & 0.07 & 0.29 & 0.86 & 0.15 \\
\hline \multicolumn{9}{|c|}{ Total number on right and left sides of proboscis. } \\
\hline
\end{tabular}

\section{Results}

The partial nucleotide sequence of 709 bp portion of the mitochondrial COI gene was analyzed for 67 individuals collected from 29 sites in Japan and Korea. Nucleotide substitutions occurred at 129 sites within the $709 \mathrm{bp}$ region
(18.2\%), distinguishing 46 haplotypes (Table 2, Figs. 2). The nucleotide sequences have been deposited in DDBJ (accession number AB603842-AB603887). Although amino acids coded by the variable sequences were conservative in most haplotypes, amino acid substitutions were detected in the following two haplotypes: in a haplotype 
A

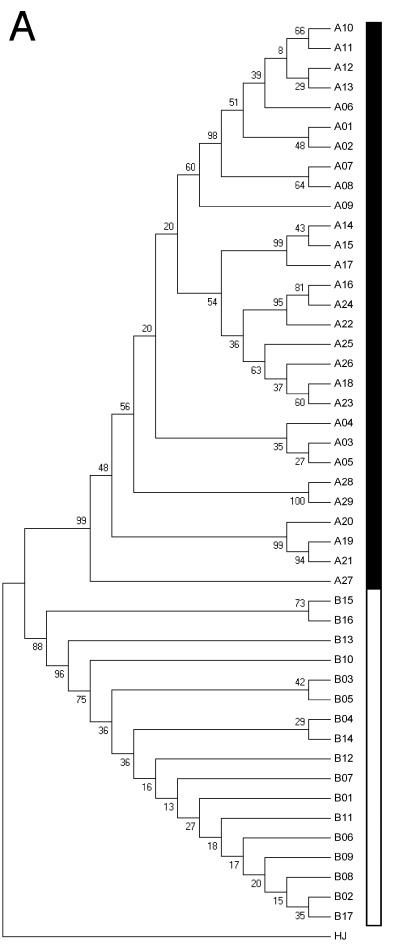

C

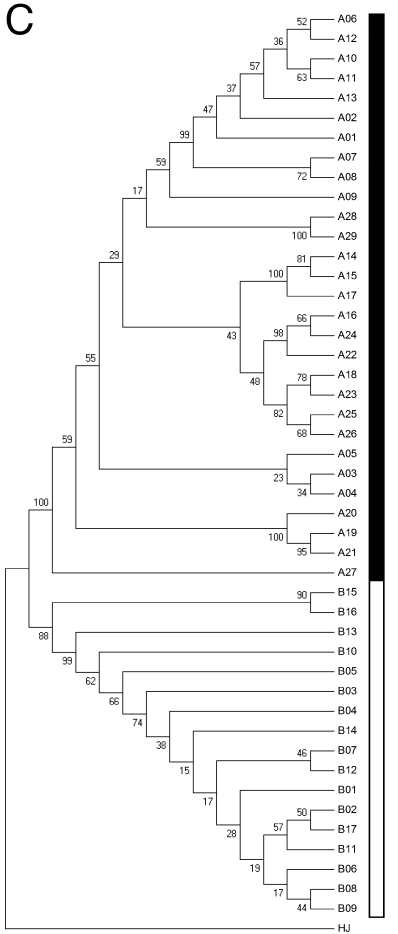

B

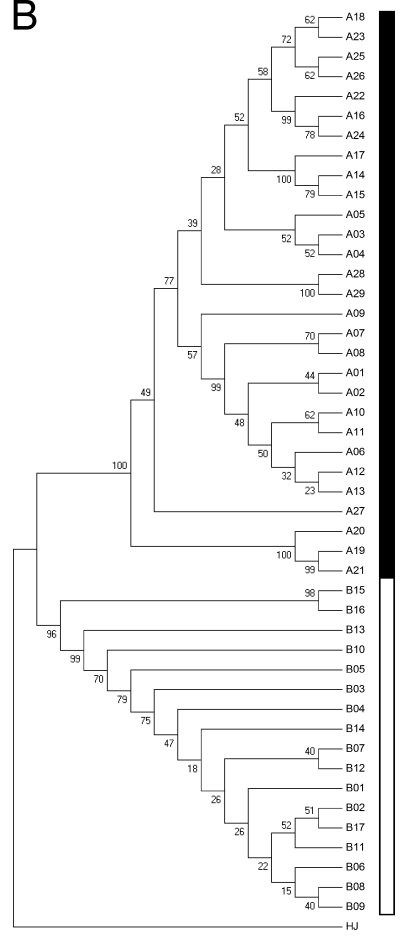

D

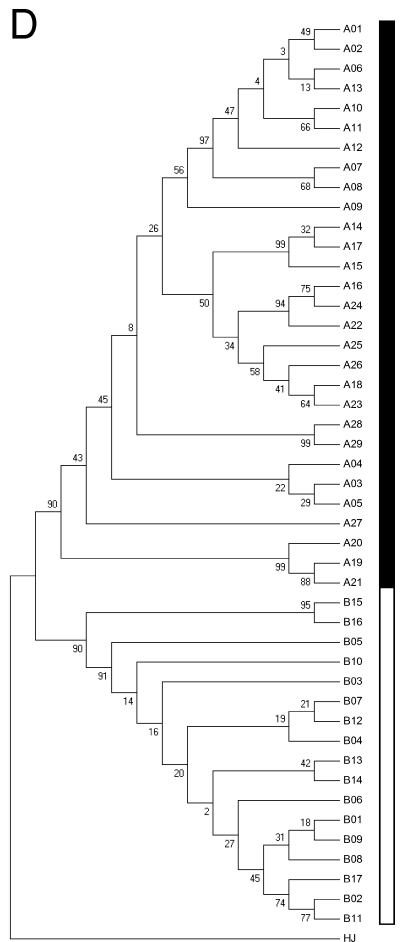

Fig. 3. Maximum likelihood (A), neighbor-joining (B), minimum evolution (C) and maximum parsimony (D) trees for haplotypes of Hediste atoka. Hediste japonica (HJ; accession number AB603758) was used as an out-group to root the in-group cluster. The percentages of replicate trees in which the associated taxa clustered together in the bootstrap test (1,000 replicates) are shown next to the branches.

(A23) from Ohhashi-gawa River (11 in Fig. 1), the 151st residue, methionine (M) was substituted by leucine (L): and in a haplotype (B11) from Kotsuki-gawa River (23 in Fig. 1 ), the 14th residue, phenylalanine (F) was substituted by tyrosine (Y).

Phylogenetic relationships among the haplotypes were analyzed using four different methods (ML, NJ, ME and MP clustering methods) (Fig. 3). All of the four different 
phylogenetic trees consistently showed that the haplotypes were divided into the same two groups, which are designated as forms A and B. Form A consisted of 29 haplotypes (47 individuals) from 21 sites, which were located in Korea and a wide range of Japan, extending north to Hokkaido and south to Kikaijima Island in the Ryukyu Islands (Fig. 1). Form B consisted of 17 haplotypes (20 individuals) from 8 sites, which were located in southern Kyushu and Amami-oshima Island in the Ryukyu Islands in Japan. The geographical distributions of these two forms did not overlap. Within form B, a population of Koshikijima Island (B15, B16) was consistently distinguishable from all other populations.

The number of paragnaths on the proboscis of each group was compared between forms A (30 individuals collected from 16 sites) and B (8 individuals collected from 6 sites) (Table 3). The paragnath numbers were rather variable with wide ranges in both forms. There was no significant difference in paragnath number of any groups between the two forms (Wilcoxon-Mann-Whitney test, $p>0.05$ ).

\section{Discussion}

The present study shows that populations of Hediste atoka consist of two genetically distinct groups, i.e., forms $\mathrm{A}$ and $\mathrm{B}$, though no morphological differentiation has been detected between them. Distributions of these two forms were parapatric; form A was widely distributed in most of Japanese and Korean coasts except for south-western Kyushu and Amami-oshima in the Ryukyu Islands, occupied by form B. The distributional ranges of these two forms did not overlap. This result suggests that cryptic speciation without morphological differentiation has occurred in $H$. atoka. Higher interpopulational genetic differentiation is expected in $H$. atoka, because its life cycle is usually restricted to brackish waters within a river due to its direct development without a true planktonic stage (Sato \& Tsuchiya 1987, 1991), and thus gene flow among populations seems to be limited (Sato \& Masuda 1997, Sato 1999), in comparison with the closely related species such as $H$. diadroma and $H$. japonica with a planktonic larval stage outside a river (Sato \& Tsuchiya 1991, Tosuji \& Sato 2006). In H. atoka, dispersal from river to river seems to be exceptionally probable by swimming juveniles (Kikuchi 1998, Sato 1999), which may flow downstream due to accidents such as a flood, and may come back to another brackish-water area.

The border between the distributions of the two forms is located in the coasts of Kyushu and the Ryukyu Islands, where no geographical barrier seems to exist. Conspicuous genetic differentiation between populations mainly distributed in coasts along the Kuroshio Current and those distributed in coasts along Tsushima Current and its branches was demonstrated by analyses of a part of the mitochondrial COI gene in the direct developing estuarine gastropod Batillaria cumingi (Crosse 1862) (Kojima et al. 2004) and the Japanese turban shell Turbo (Batillus) cornutus Lightfoot, 1786 with a short planktonic period (Kojima et al. 1997, 2000). But, in the present study, no such marked geographical differentiation associated with the Kuroshio Current and Tsushima Current was detected.

It is unknown how the parapatric distributions of the two forms of $H$. atoka have been established and maintained. Some historical events in an area around southern Kyushu and the Ryukyu Islands may relate to the differentiation of the two forms. Competition between the two forms may relate to their exclusive distribution. To shed light on this problem, further analyses are needed to ascertain details of distributions of the two forms in Kyushu and the Ryukyu Islands. It seems also important to examine relationships among the two forms of $H$. atoka and H. diadroma, which is morphologically very similar to $H$. atoka, and commonly coexists with it (Sato \& Nakashima 2003).

\section{Acknowledgments}

We thank Jae-Sang Hong (Inha University), Hiroaki Tsutsumi (Prefectural University of Kumamoto), Gen Kanaya (Tohoku University), Takao Suzuki (Tohoku University), Sayumi Isaka (Hokkaido University), Kenshi Toda (Shimane Environment \& Health Public Corporation), Hajime Saito (Fisheries Research Agency) for help in collecting materials.

\section{References}

Audzijonyte A, Ovcarenko I, Bastrop R, Väinölä R (2008) Two cryptic species of the Hediste diversicolor group (Polychaeta, Nereididae) in the Baltic Sea, with mitochondrial signature of different population histories. Mar Biol 155: 599-612.

Bastrop R, Blank M (2006) Multiple invasions - a polychaete genus enters the Baltic Sea. Biol Invasions 8: 1195-1200.

Bastrop R, Jürss K, Sturmbauer C (1998) Cryptic species in a marine polychaete and their independent introduction from North America to Europe. Mol Biol Evol 15: 97-103.

Bickford D, Lohman DJ, Sodhi NS, Ng PKL, Meier R, Winker K, Ingram KK, Das I (2006) Cryptic species as a window on diversity and conservation. Trends Ecol Evol 22: 148-155.

Blank M, Laine AO, Jürss K, Bastrop R (2008) Molecular identification key based on PCR/RFLP for three polychaete sibling species of the genus Marenzelleria, and the species' current distribution in the Baltic Sea. Helgol Mar Res 62: 129-141.

Eck RV, Dayhoff MO (1966) Atlas of Protein Sequence and Structure. National Biomedical Research Foundation, Silver Springs, Maryland.

Folmer O, Black M, Hoeh W, Lutz R, Vrijenhoek R (1994) DNA primers for amplication of mitochondrial cytochrome $c$ oxidase subunit I from diverse metazoan invertebrates. Mol Mar Biol Biotechnol 3: 294-299.

Imajima M (1972) Review of the annelid worms of the family Nereidae of Japan, with descriptions of five new species or subspecies. Bull Natl Sci Mus Tokyo 15: 37-153.

Jolly MT, Jollivet D, Gentil F, Thiébaut E, Viard F (2004) Sharp 
genetic break between Atlantic and English Channel populations of the polychaete Pectinaria koreni, along the North coast of France. Heredity 94: 23-32.

Kikuchi E (1998) Life history and dispersal pattern of the polychaete worm Neanthes japonica (Izuka) in the Nanakita River Estuary, Miyagi Prefecture. Jpn J Limnol 59: 125-146.

Kojima S, Hayashi I, Kim D, Iijima A, Furota T (2004) Phylogeography of an intertidal direct-developing gastropod Batillaria cumingi around the Japanese Islands. Mar Ecol Prog Ser 276: 161-172.

Kojima S, Segawa R, Hayashi I (1997) Genetic differentiation among populations of the Japanese turban shell Turbo (Batillus) cornutus corresponding to warm currents. Mar Ecol Prog Ser 150: 149-155.

Kojima S, Segawa R, Hayashi I (2000) Stability of the Courses of the Warm Coastal Currents along the Kyushu Island Suggested by the Population Structure of the Japanese Turban Shell, Turbo (Batillus) cornutus. J Oceanogr 56: 601-604.

Rzhetsky A, Nei M (1992) A simple method for estimationg and testing minimum-evolution trees. Mol Biol Evol 9: 945-967.

Saitou N, Nei M (1987) The neighbor-joining method: A new method for reconstructing phylogenetic trees. Mol Biol Evol 4: 406-425.

Sato M (1999) Divergence of reproductive and developmental characteristics in Hediste (Polychaeta: Nereididae). Hydrobiologia 402: 129-143.

Sato M (2004) Diversity of polychaetes and environments in tidal flats: A study on the Hediste species group (Nereididae). Fossils 76: 122-133. (in Japanese with English abstract)

Sato M, Masuda T (1997) Genetic differentiation in two sibling species of the brackish-water polychaete Hediste japonica complex (Nereididae). Mar Biol 130: 163-170.

Sato M, Nakashima A (2003) A review of Asian Hediste species complex (Nereididae, Polychaeta) with descriptions of two new species and a redescription of Hediste japonica (Izuka, 1908). Zool J Linn Soc 137: 403-445.

Sato M, Tsuchiya M (1987) Reproductive behavior and salinity favorable for early development in two types of the brackishwater polychaete Neanthes japonica (Izuka). Benthos Res 31: 29-42.

Sato M, Tsuchiya M (1991) Two patterns of early development in nereidid polychaetes keying out to Neanthes japonica (Izuka). Ophelia Suppl 5: 371-382.

Tamura K, Dudley J, Nei M, Kumar S (2007) MEGA4: Molecular Evolutionary Genetics Analysis (MEGA) software version 4.0. Mol Biol Evol 24: 1596-1599.

Tamura K, Nei M (1993) Estimation of the number of nucleotides substitutions in the control region of mitochondrial DNA in humans and chimpanzees. Mol Biol Evol 10: 512-526.

Tosuji H, Sato M (2006) Salinity favorable for early development and gamete compatibility in two sympatric estuarine species of the genus Hediste (Polychaeta: Nereididae) in the Ariake Sea, Japan. Mar Biol 148: 529-539.

Tosuji H, Sato M (2008) Identification of three Asian Hediste species (Polychaeta: Nereididae) by PCR-RFLP analysis of the mitochondrial 16S rRNA gene. Plankton Benthos Res 3: 50-52.

Virgilio M, Fauvelot C, Constantini F, Abbiati M, Backeljau T (2009) Phylogeography of the common ragworm Hediste diversicolor (Polychaeta: Nereididae) reveals cryptic diversity and multiple colonization events across its distribution. Mol Ecol 18: 1980-1994.

Westheide W, Hass-Cordes E (2001) Molecular taxonomy: description of a cryptic Petitia species (Polychaeta: Syllidae) from the island of Mahé (Seychelles, Indian Ocean) using RAPD markers and ITS2 sequences. J Zool Syst Evol Res 39: 103111. 